much light on key elements in the evolution of British economic policy in the postwar decades. This is an original and illuminating book about high finance in Britain in the years before it became proud, but it is more than just a book about finance. Above all, Davies's book demonstrates the centrality of the banks to any wider consideration of political economy in postwar Britain: all who are interested in that critical question should read it.

\author{
John Davis \\ The Queen's College \\ Oxford, OXI 4AW, United Kingdom \\ E-mail: john.davis@history.ox.ac.uk \\ doi:10.1017/S0020859018000457
}

Countryside and Communism in Eastern Europe. Perceptions, Attitudes, Propaganda. Ed. by Sorin Radu and Cosmin Budeancă. [Mainzer Beiträge zur Geschichte Osteuropas, Bd. 8.] LIT Verlag. Vienna [etc.] 2016. 798 pp. $£ 69.90$.

The history of state socialism has been a contested field of study and often subject to ideological rather than academic debates. Further, the study of communism in the countryside alongside the tragic history of collectivization triggered the interest of the academic and wider public mainly in areas and topics linked with the history of Soviet Russia and the most horrible consequence of state violence against the villages, that of the great famine. With few exceptions, Eastern Europe - and especially the comparative study of the former satellite countries - remained a considerably less "sexy" topic than the collectivization and subsequent transformation of Soviet village life, which went hand in hand with forced industrialization and whose story inspired so many scholars to develop various interpretations of the character and evaluation of the historical era we conveniently refer to as Stalinism.

Unlike the history of Soviet collectivization, which has been written from various perspectives - totalitarian, revisionist, and post-totalitarian - the individual Eastern European narratives mainly fit within a singular paradigm - that of the totalitarian interpretation of the Stalinist-type dictatorship, which had been "exported" to the satellite states with the outbreak of the Cold War. National history-writing in Eastern Europe experienced a new renaissance after the collapse of communist rule in the region, and in the individual narratives the Soviet Union was depicted as the ultimate evil, which deterred the independent national histories from taking the right path and, in the postwar era, prevented the establishment of democratic governance and of a well-functioning, welfare capitalist society in the region. Collectivization was interpreted merely as a brutal attack on traditional agricultural life and moral values, which were understood as the "essence of national identity". It was therefore connected with brutality, aggression, the abuse of power by the state (at the least), the loss of legitimacy on the part of communist leaders (assuming they had any), and the violent and forced transformation of village life, which merely paved the way for building the hated Stalinist-type society. Indeed, in the new intellectual climate, which demanded new discourses of legitimacy, there were few "native" attempts to go beyond totalitarianism and follow the lead of Western scholars. They were familiar with the debates 
on totalitarianism and adapted a revisionist or a post-totalitarian perspective - as Katherine Verdery did in the Romanian case, and Nigel Swain and Chris Hann, who conducted fieldwork in Hungary. ${ }^{\mathrm{I}}$

We therefore have to welcome the inspiring attempt by Sorin Radu and Cosmin Budeancă. Firstly, for going beyond the ethno-national narratives, and for trying to find a common pattern in the various strategies of collectivization in Eastern Europe, and for showing how official propaganda shaped the transformation of village life, the forms of resistance, and the techniques of adaptation. Secondly, for their attempt to give a comparative picture of the making of the "communist" countryside. This is not an easy task if we take into account the various languages and scholarly communities whose cooperation is needed. The aspiration to think post-totalitarian is clearly expressed in Radu's introduction, which offers a strong theoretical guide to the existing literature on the Soviet and Eastern European communist experiment: "In this context we also claim together with Kevin McDermott, [and] Matthew Stibbe, that the communist parties were not based solely on the political repression for the institutionalization of the totalitarian regimes" (p. 36).

This extensive volume, which is the result of an admirable attempt to bring together scholars of the region and bridge their individual achievements, meets the aims and standards set in the introduction. The thirty-five authors who contributed to the volume, based on most of the papers presented at the eponymous conference, fruitfully combine the posttotalitarian Western theoretical concepts and interdisciplinary methods with local knowledge and detailed case studies. One of the themes covered highlights an often-neglected fact: that with the consolidation of the state-socialist regimes, it was not only the urban population whom the regime sought to win over through the promise of "socialist consumerism" and improved living standards (not only by wage increases, but also socialist welfare provisions, leisure activities, upward social mobility), the rural population, too, was targeted, albeit only with the end of high Stalinism. Overall, therefore, the book offers an oscillating picture of collectivization, where state policies ranging from ruthless oppression to the extension of socialist consumerism to rural areas shaped not only the transformation of village life, but also the modes of adaptation and survival (or escape) strategies.

The thirty contributions included in this volume cover a wide range of subjects: from the institutionalization of communist rule in the countryside (building of party structures, particularly difficult in rural areas, where even cadres were missing, the early difficulties of organizing the peasants in various Eastern European countries), through the analysis of the implementation of collectivization and its effects, the methods of coercion and the attempts of resistance, the role of the secret police in the countryside, the transformation of rural mentality, communist propaganda, and the representation of peasants in official ideology, the persecution of rich peasants, to the exploitation of ethnic differences in propaganda. An important merit of the book is not only its wide range of topics, but also the inclusion of "unusual" themes, which are usually missing from the "native" Eastern European narratives: these include discussion of the political activity of worker-peasants, and the

I. Katherine Verdery, The Vanishing Hectare: Property and Value in Postsocialist Transylvania (Ithaca, NY, 2003); Michael Burawoy and Katherine Verdery (eds), Uncertain Transition: Ethnographies of Change in the Postsocialist World (Boulder, CO, I999); Chris Hann (ed.), Postsocialism: Ideals, Ideologies and Practices in Eurasia (London, 200I); Nigel Swain, Green Barons, Force-ofCircumstance Entrepreneurs, Impotent Mayors: Rural Change in the Early Years of Post-Socialist Capitalist Democracy (Budapest, 2013). 
exploration of how gender influenced the accommodation of communist rule in the countryside. Even the relationship between politics, nature, and the environment is included: for instance, the discussion of the programme of afforestation in Hungary, and the implementation of the programme to transform nature in line with communist propaganda.

Countryside and Communism in Eastern Europe is thus a fruitful attempt to engage in a more balanced history-writing in the region, that goes beyond the national narratives and writes the complex history of the collectivization in Eastern Europe from various perspectives. This is particularly true if we think of the wide range of topics discussed in the volume. There is a strong reflection on the fact that the communist policies were not implemented in a "social vacuum"; although these policies clearly aimed at transforming village life, there was a limited space of action for the peasants (in the form of accommodation, escape, or even resistance). One welcomes the fact that aspects of gender and environmental change are represented in the volume. Regarding the first, this volume shows how the communist regimes eventually made concessions to traditionalism, the good mother and housewife remaining the primary social role with which rural women identified - at least in Poland. I add here a minor criticism: since this was the case certainly in Hungary, it would be useful for future research to add a comparative perspective. Regarding the latter, the volume highlights the environmentally detrimental effects of the ideologically dependent research.

While the regime sought to abolish peasants as a class (in spite of the frequently propagated worker-peasant alliance in all of its propaganda), social differences proved to be resilient in the countryside, where new social differences were created by party policy. It is important that the volume raises the problem of worker-peasants, and it demonstrates that rural workers unable to commute daily were more prone to engage in open protest than their urban counterparts, who were daily commuters. Such differences could be also detected even before the collapse of communist rule in the region.

So far, I have listed the merits of the volume; however, some deficiencies should also be mentioned. I have already stressed the importance of the discussion of gender and new social groups formed in the countryside, including the worker-peasants; the volume is lengthy enough, but some more social history and social anthropology would have useful. How were the worker-peasants represented in official discourse? How did gender impact the strategies of adaptation and resistance to the communist transformation of the countryside in countries other than Poland? What did socialist consumerism mean in the countryside? How did leisure time change in rural areas? Of course, new questions can be endlessly expanded. One hopes that in a subsequent volume such questions could be further studied and explored.

Another problem presented by this volume is the lack of a conclusion on the comparative aspects of the papers presented. While it is understood that there are many objective obstacles to researching and writing cross-comparative papers (language difficulties, the costs of conducting research in foreign countries), it would have been useful to present conclusions explicitly informing the reader of the similarities and differences in the implementation and social and economic impacts of collectivization in the different countries. Additional cross-comparative studies would also be welcome.

Despite the above shortcomings, this volume is undoubtedly a fresh and inspiring experiment in opening up new chapters in the study of collectivization in Eastern Europe. It carefully balances political and institutional history with various aspects of social history, thus offering novel insights into the life of the rural population in an era when political 
power massively intervened in traditional life. The organization and establishment of party structures in the countryside was rendered difficult in every country because the communists were unpopular among the peasants. Land distribution increased the popularity of the party, but collectivization ultimately turned peasants against the ruling political elite. In the Hungarian case, the bitterness and anger of both workers and peasants led to open and armed resistance and the 1956 Revolution. High Stalinism was eventually replaced with a new course, in which collectivization was accompanied by a policy of appeasement and the peasants' renouncement of open resistance. Rural mentality oscillated between traditionalism, materialism, and the renouncement of collective action. Continued study of the social and political behaviour of worker-peasants would therefore contribute to our understanding of the changes in the political mobilization of the peasantry. It is to be hoped that the large-scale research and publication experiment of Countryside and Communism will continue in Eastern Europe.

\section{Eszter Bartha}

Department of Eastern European Studies, Eötvös Loránd University of Budapest 4-6 Múzem krt., Budapest, H-ı 088 , Hungary

E-mail: barthaeszter@hotmail.com doi: $10.1017 /$ S002085901 8000469

Semán, Ernesto. Ambassadors of the Working Class. Argentina's International Labor Activists \& Cold War Democracy in the Americas. Duke University Press, Durham (NC) 2017. xiii, 3 I 4 Pp. Ill. \$94.95. (Paper: \$26.95).

A few weeks after taking office in 1946, President Juan Perón created the Worker Attaché Programme. This new position of worker attaché within the Argentine Foreign Service was designed to promote Peronism as a path for the expansion of working-class social and political rights throughout the world. More specifically, these worker attachés were to confront US labour diplomats to win influence over the region's labour movement.

Selected by the General Confederation of Labour (CGT), the future officials were rankand-file union members from across the country, mostly from leftist (anarchist, socialist, or communist) backgrounds. The programme was dismantled following the 1955 military coup that ousted the Peronists from power for eighteen years. During the period it endured, the two-month training course initially envisaged became one of two years. By I949, around a hundred activists had been sent to embassies worldwide, while a similar number fulfilled related tasks at the Foreign Ministry in Buenos Aires, the CGT, or at their own unions. Approximately 500 workers - among them very few women - received their diplomas as official worker attachés. Although borrowing from previous foreign experiences and local ideas, this programme was unique in assigning such a high proportion of blue-collar workers to diplomatic duties, and it was the first government-led effort in Argentina to professionalize its foreign service. While the working-class origin of the worker attachés was exasperating for the traditional elitist Argentinian diplomatic corps, the attachés' mission to spread Perón's gospel of social revolution brought outright anxiety abroad.

The author draws on diplomatic dispatches and reports (many of them found uncatalogued at various Argentine embassies), personal papers and memoires treasured by relatives, 